\title{
Risk and Prevention of Hepatitis B Virus Reactivation during Immunosuppression for Non-Oncological Diseases
}

\author{
Lorenzo Onorato ${ }^{1,2}$, Mariantonietta Pisaturo ${ }^{1}$, Clarissa Camaioni ${ }^{1}$, Pierantonio Grimaldi ${ }^{1}$, \\ Alessio Vinicio Codella ${ }^{2}$, Federica Calò ${ }^{2}$ and Nicola Coppola ${ }^{1,2, *(1)}$ \\ 1 Department of Mental Health and Public Medicine, Faculty of Medicine, University of Campania Luigi \\ Vanvitelli, Via L. Armanni 5, 80138 Naples, Italy; lorenzoonorato@libero.it (L.O.); \\ mariantonietta.pisaturo@unicampania.it (M.P.); clarissacamaioni91@gmail.com (C.C.); \\ peogrimaldi@me.com (P.G.) \\ 2 Infectious Diseases Unit, Azienda Ospedaliera Universitaria Luigi Vanvitelli, Via Pansini 5, \\ 80138 Naples, Italy; alessiovinicio.codella@studenti.unicampania.it (A.V.C.); fede.calo85@gmail.com (F.C.) \\ * Correspondence: nicola.coppola@unicampania.it
}

Citation: Onorato, L.; Pisaturo, M. Camaioni, C.; Grimaldi, P.; Codella, A.V.; Calò, F.; Coppola, N. Risk and Prevention of Hepatitis B Virus Reactivation during

Immunosuppression for

Non-Oncological Diseases. J. Clin Med. 2021, 10, 5201. https://doi.org/ $10.3390 /$ jcm 10215201

Academic Editors: Davide Giuseppe Ribaldone and Gian Paolo Caviglia

Received: 3 September 2021 Accepted: 3 November 2021 Published: 8 November 2021

Publisher's Note: MDPI stays neutral with regard to jurisdictional claims in published maps and institutional affiliations.

Copyright: (c) 2021 by the authors. Licensee MDPI, Basel, Switzerland. This article is an open access article distributed under the terms and conditions of the Creative Commons Attribution (CC BY) license (https:// creativecommons.org/licenses/by/ $4.0 /)$.

\begin{abstract}
Reactivation of overt or occult HBV infection (HBVr) is a well-known, potentially lifethreatening event which can occur during the course of immunosuppressive treatments. Although it has been described mainly in subjects receiving therapy for oncological or hematological diseases, the increasing use of immunosuppressant agents in non-oncological patients observed in recent years has raised concerns about the risk of reactivation in several other settings. However, few data can be found in the literature on the occurrence of HBVr in these populations, and few clear recommendations on its management have been defined. The present paper was written to provide an overview of the risk of HBV reactivation in non-neoplastic patients treated with immunosuppressive drugs, particularly for rheumatological, gastrointestinal, dermatological and neurological diseases, and for COVID-19 patients receiving immunomodulating agents; and to discuss the potential strategies for prevention and treatment of HBVr in these settings.
\end{abstract}

Keywords: HBV infection; HBV reactivation; rheumatological diseases; gastrointestinal diseases; neurological diseases; dermatological diseases

\section{Introduction}

Hepatitis B virus (HBV) represents one of the most important threats for public health. According to the WHO estimates, approximately 3.5\% of the global population was living with a chronic HBV infection in 2015, and about 900,000 people died during the same year from HBV-related cirrhosis or hepatocellular carcinoma [1]. Furthermore, after HBsAg loss, the viral genome may persist in the hepatocytes, leading to a condition known as "occult HBV infection" (OBI), which is defined as the presence of replication of competent HBV DNA in the liver and/or blood of subjects testing negative for HBsAg [2].

In recent years, the increasing use of immunosuppressive treatments has led to a growing incidence of $\mathrm{HBV}$ reactivation $(\mathrm{HBVr})$ in patients with overt or occult infection [3]. As a systematic review recently published by our group estimated a prevalence of OBI in Western countries ranging from $19 \%$ to $51 \%$ [4], and considering the incidence of immunosuppressive diseases and/or the use of immunosuppressive treatments, the risk of $\mathrm{HBVr}$ has become high. Life-threatening reactivation episodes have frequently been described in subjects undergoing immune suppression for oncological or hematological diseases $[5,6]$; however, little is known about the risk of HBVr in patients treated with immunosuppressants in other settings, such as rheumatological, gastroenterological, neurological, or dermatological diseases, and most recently for SARS-CoV-2 pneumonia.

The present paper was written to provide an overview of the risk of reactivation of HBV infection in non-oncological and non-hematological settings, and to discuss the strategies for preventing and treating these life-threatening events. 


\section{Epidemiology of HBV Infection}

HBV belongs to the Hepadnaviridae family, which includes viruses with doublestranded DNA and lipoprotein envelopes. It mainly infects hepatocytes and is one of the most widespread viruses in the world. Despite the incisive vaccination programs that have been carried out, HBV still remains a global health problem due to its enormous burden in terms of morbidity and mortality. In fact, this virus can cause various clinical manifestations: acute hepatitis B, inactive carrier state, and chronic hepatitis B, which can lead to liver cirrhosis and hepatocellular carcinoma [7].

The WHO estimated that in 2015, chronic HBV infections affected about 257 million people in the world, $68 \%$ of whom lived in Africa and the Western Pacific [8]. We should point out that the prevalence of infection varies considerably by geographical area: in the African regions, it is 4.6-8.5\%; in the Western Pacific region, 6.2-7.6\%; in the East Mediterranean regions, the prevalence fluctuates between $2.6 \%$ and $4.3 \%$; in South East Asia between $1.5 \%$ and $4 \%$; in Europe between $1.2 \%$ and $2.6 \%$; and finally, in North America, between $0.7 \%$ and $1.6 \%$ of the population is estimated to be HBsAg-positive [8].

In the regions with the highest prevalence, infection is mainly transmitted through the vertical route or as a result of intrafamily contacts, and therefore, it is acquired at birth or at an early age. These transmission routes contribute to maintaining high endemicity in these areas, especially given the high rate of chronicization reported when the infection is contracted during the first years of life. In regions with low prevalence, on the other hand, HBV is acquired mainly in adulthood by sexual or parenteral contact; but in these regions high HBsAg prevalence can be found in specific groups, such as among immigrants from areas with high endemicity [9], people who inject drugs (PWID), men who have sex with men (MSM), and people living with HIV (PLWHIV) [10].

Thanks to the extensive vaccination programs carried out, the prevalence of chronic hepatitis B among children under the age of 5 fell to below 1\% in 2019 (compared to 5\% in the pre-vaccination period or up to 2000), but the goal planned by the WHO-to eliminate HBV infection as a major health problem—is still far from being achieved [11].

\section{Natural History of HBV Infection}

The natural history of chronic HBV infection has been divided into five phases, according to the HBeAg serostatus, the viral load, the transaminase levels, and the grading and staging of liver disease [12]. A HBeAg-positive chronic infection, previously called "immunotolerant phase", is characterized by a limited or absent immune response against the virus, which leads to intense viral replication, with $\mathrm{HBeAg}$ positivity, ALT persistently in the normal range, and no or minimal liver necroinflammation or fibrosis. During the second phase, currently named "HBeAg-positive chronic hepatitis", the host produces an active immune response against viral antigens, causing a consequent reduction in viral load, and elevation of transaminase levels and liver inflammation. The immune response can eventually lead to control of the infection, with HBeAg seroclearance, low level replication (HBV DNA < $2000 \mathrm{UI} / \mathrm{mL}$ ), absence of ALT elevation, and mild or no necroinflammation in the liver: these features define the phase of "HBeAg-negative chronic infection". The acquisition of mutations in the pre-core or basal core promoter regions, however, may allow high-level viral replication despite the presence of antibodies against $\mathrm{HBe} \mathrm{Ag}$, and lead to elevation of the viral load and liver enzymes, concurrent moderate to severe liver inflammation, and rapid progression of disease. Finally, as previously described, after the HBsAg clearance, the viral genome can still remain detectable in the liver or plasma, defining the "HBsAg-negative phase" or "occult B infection"; several data suggest that the persistence of low-level replication in patients with occult infections can contribute to the advancement of liver fibrosis and the development of hepatocellular cancer in patients with other etiologies of liver disease, particularly hepatitis $C$ virus (HCV) infections [13,14].

In patients with chronic hepatitis, the cumulative 5-year incidence of progression to cirrhosis is estimated to be $8-20 \%$. The wide variability can be determined by the viral load, the HBeAg serostatus, and the presence of concomitant alcohol abuse or coinfection with 
HCV, hepatitis Delta virus (HDV), or human immunodeficiency virus (HIV) [15]. Once cirrhosis occurs, the risk of decompensation is estimated to be around $20-25 \%$ per year, and the 5-year survival is $20-30 \%$ [16]. Moreover, about $5-15 \%$ of cirrhotic patients develop hepatocellular cancer during their lives [17].

\section{HBV Reactivation following Immunosuppressive Treatments}

Although many definitions have been proposed, $\mathrm{HBV}$ reactivation commonly refers to either the de novo detection of HBV DNA or a $\geq 10$-fold increase in HBV DNA level compared with the baseline value in HBsAg-positive patients, and seroconversion to HBsAg-positive status in previously negative subjects [18]. The biological basis of $\mathrm{HBVr}$ is the persistence of the viral genome as ccc-DNA in liver cells.

Several risks factors for the occurrence of reactivation after immune suppression have been identified [19].

As regards the host characteristics, the most important factor is the HBV immune control preceding the treatment. Obviously, patients with chronic HBV infections are significantly more at risk of reactivation compared to subjects with OBI, as demonstrated by several studies in both oncological [20] and non-oncological settings [21,22]. Furthermore, among HBsAg-negative subjects, the presence of anti-HBs has been related to a lower risk of reactivation, as demonstrated by Seto et al. [23] among 63 patients receiving rituximab for hematological malignancies. Other host factors that have been related to increased risk of reactivation include male gender [24], older age [25], and underlying lymphoproliferative diseases [5].

According to the agent used and the serostatus of the patient, the risk of $\mathrm{HBVr}$ can be roughly classified into high risk (frequency of reactivation $>10 \%$ in the absence of prophylaxis), medium risk $(1-10 \%)$, or low risk $(<1 \%)[18,26,27]$. It is well known that the use of specific drugs, such as B-cell depleting agents, is associated with a high risk of reactivation in patients with both overt and occult infections [28]. Other drug classes that can cause reactivation in more than $10 \%$ of cases among HBsAg-positive subjects include anthracycline derivatives [20] and high dose corticosteroids (20 mg daily of prednisone or equivalent) administered for more than 4 weeks of treatment [18]. In particular, glucocorticoids have been demonstrated to directly stimulate HBV replication in hepatoma cells through the activation of regulatory elements [29]. Additional drug classes that have been related to reactivation in patients with overt and/or occult HBV infections include inhibitors of TNF-alfa [22] or other cytokine or integrin inhibitors [30], and tyrosine kinases [31] and JAK inhibitors [21]. Many of these agents have been used increasingly in recent years in non-oncological settings, such as rheumatological diseases or inflammatory bowel diseases, but less clear data on their impacts on HBV infection are available so far among non-oncological populations.

\section{Strategies for the Prevention and Treatment of HBV Reactivation}

Since the likelihood of HBV reactivation depends on the type, duration, and intensity of the immunosuppression, therapeutic strategies aimed at avoiding HBV reactivation are modulated according to the risk profile of reactivation. The algorithm of $\mathrm{HBVr}$ prevention according to HBsAg serostatus and risk of reactivation is shown in Figure 1.

Considering the phases of HBV infection, the patients with chronic hepatitis are at high risk for HBVr and progression of liver damage, so and they should be evaluated for treatment. Those with HBeAg-positive or $\mathrm{HBeAg}$-negative chronic infections and those with previous infections show various risks of reactivation, and should be evaluated for HBV prophylaxis or pre-emptive therapy according to the immunosuppressive regimens they will undergo [12]. 


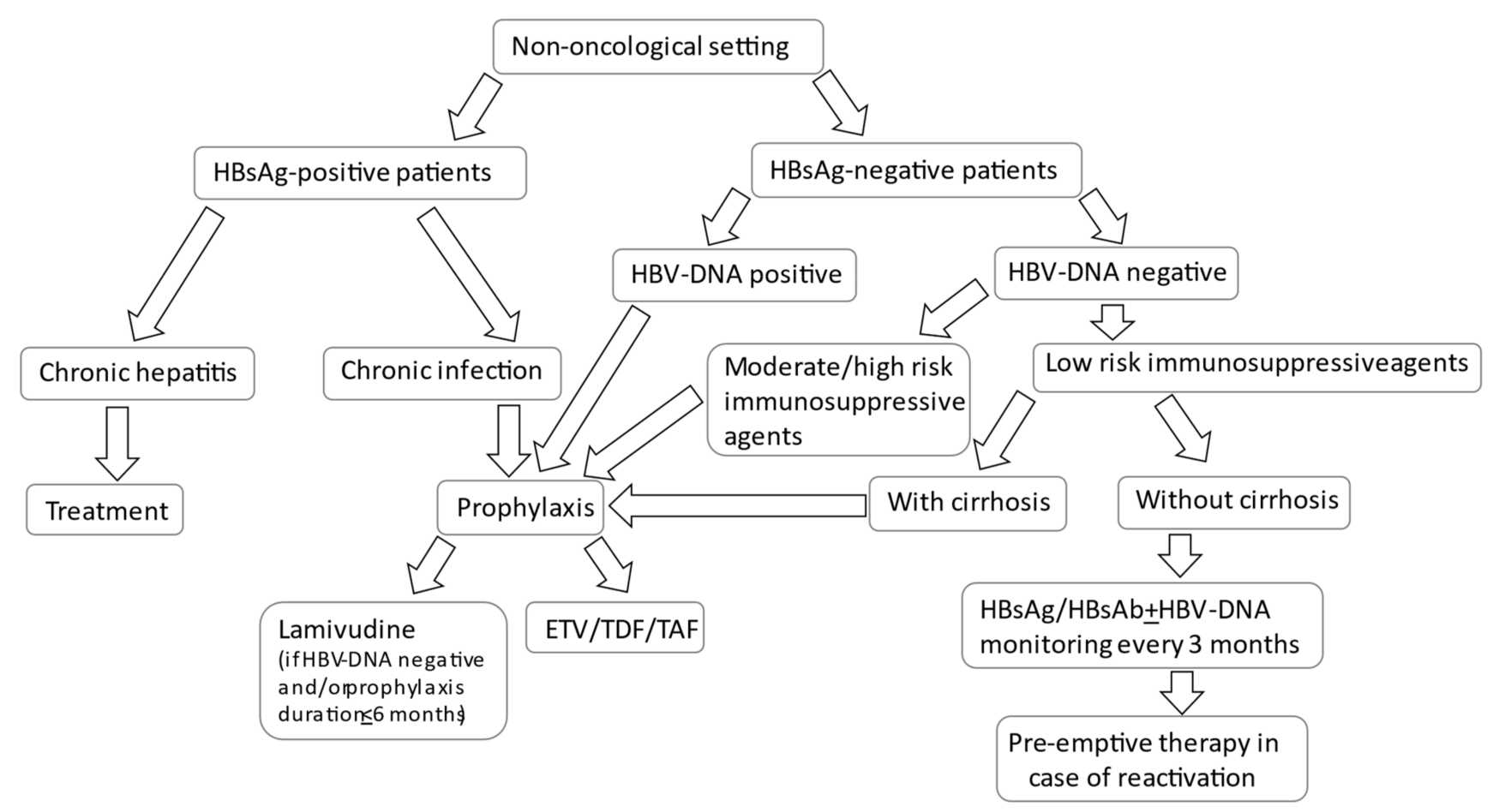

Figure 1. Algorithm of HBVr management in patients undergoing immunosuppression for non-oncological diseases.

In the patients with HBV-related hepatitis, a therapy with high genetic barrier nucleos(t)ide analogues (entecavir (ETV), tenofovir (TDF), or tenofovir alafenamide (TAF)) should be started as soon as possible, as for non-immunocompromised subjects, so this is considered therapy and not prophylaxis [12,32-35].

Instead, in patients with HBV infections undergoing treatments that involve moderatehigh risks of reactivation, some form of prophylaxis should be prescribed, preferably an antiviral drug with a high genetic barrier, i.e., ETV, TDF, or TAF, as recommended by international guidelines [12,32]. Lamivudine was the first nucleoside analogue used as antiviral prophylaxis to reduce $\mathrm{HBVr}$ complications; however, the development of resistance in patients requiring prolonged duration of therapy may lead to a re-emergence of HBV DNA and a risk of $\mathrm{HBVr}$, so newer nucleoside agents with high barriers to resistance may provide additional options for antiviral prophylaxis [36]. According to the guidelines of the American Gastroenterological Association (AGA), the use of lamivudine should be limited to the prophylaxis of patients with undetectable viral loads at baseline or with expected durations of prophylaxis of less than 6 months [32].

The prophylaxis should be started before the prescription of the immunosuppressive regimen and continued until 12-18 months after the discontinuation of the treatment [32,37-39].

HBsAg-negative, anti-HBc-positive patients should be considered for antiviral prophylaxis or pre-emptive therapy according to the HBV DNA at baseline.

Patients with positive HBV DNA at baseline should receive prophylaxis similarly to patients with overt infections. Conversely, the management depends on the risk of HBV reactivation: when the risk of reactivation is high (e.g., the use of B-cell depleting agents), a prophylactic agent should be prescribed. In the case of a moderate risk of reactivation, the correct strategy is still a matter of debate. The guidelines of the European Association for Study of Liver (EASL) recommend a pre-empitve therapy strategy [12], although a prophylaxis can be considered, according to the AGA guidelines [32]. Instead, with a low risk of reactivation, a strategy based on pre-emptive therapy is generally recommended. Patients should undergo close monitoring during and after the immunosuppression. If HBsAg seroreversion occurs, antiviral therapy with a nucleos(t)ide analogue should be initiated. 
However, in select patients with previous infection and low risk of reactivation, but with advanced liver disease due to a different etiology, lamivudine prophylaxis may be considered, to avoid the risk of a life-threatening hepatic failure following the reactivation $[12,32,40,41]$.

As regards the monitoring of the patients for whom prophylaxis is envisaged, liver function tests and HBV DNA for patients with HBV infections and HBV DNA/HBsAg tests for patients with resolved HBV infection should be performed every 3-6 months during prophylaxis and up to 12-18 months after stopping the antiviral treatment, as an episode of reactivation can still occur after the interruption of the antiviral therapy. Instead, in patients with HBV related diseases for whom therapy is envisaged, virological and biochemical monitoring is lifelong [12,32].

In the following sections we discuss the risk of reactivation related to the use of immunosuppressant agents in non-oncological settings and provide an overview of the possible management strategies.

\subsection{Risk of HBV Reactivation in Gastroenterological Diseases}

Autoimmune and inflammatory disorders, such as Crohn's disease and ulcerative colitis, are common gastroenterological conditions that often require the use of immunosuppressive therapies. Disease severity and the relapsing and remitting course affect the selection of the right drug. Agents commonly used include corticosteroids, immunomodulator agents (e.g., azathioprine/mercaptopurine and methotrexate), biological therapies (i.e., tumor necrosis factor (TNF) inhibitors), anti-adhesion therapy, anti-IL12/23 p40 antibody, and Janus kinase (JAK) inhibitor in the ultra-refractory cases.

A list of studies evaluating the risk of $\mathrm{HBV}$ reactivation in patients with gastroenteric diseases treated with immunosuppressive agents is reported in Table 1. In a retrospective study of 8887 patients treated with TNF inhibitors for autoimmune disorders, $\mathrm{HBVr}$ was observed in 9 of the $23 \mathrm{HBsAg}$-positive patients and 2 of 4267 patients in the unknown HBV status group [22]. Concomitant immunosuppressives, including steroids and nonbiological immunosuppressants, were also associated with HBVr.

In a Spanish multicenter analysis of 162 patients with inflammatory bowel disease (IBD) treated with different immunosuppressant drugs, the authors described HBVr in 9 (36\%) out of the $25 \mathrm{HBsAg}$-positive patients; however, none of the HBsAg-negative but anti-HBc positive subjects patients reported $\mathrm{HBVr}$ [42]. In addition, the authors found that treatment with $\geq 2$ immunosuppressive agents was an independent predictor of $\mathrm{HBVr}$ (OR 8.75 ; 95\% CI 1.16-65.66).

Morisco et al. [43], in a retrospective study, evaluated 5096 patients with IBD and found a lower rate of $\mathrm{HBVr}$; indeed, $\mathrm{HBVr}$ was detected in only one of six (16\%) HBsAg-positive patients treated with a therapeutic regimen that included infliximab and azathioprine.

In a systematic review evaluating 257 subjects with positive hepatitis B markers ( 89 were HBsAg-positive and 168 were HBsAg-negative/anti-HBc-positive carriers) treated with anti-TNF inhibitors for IBD and other autoimmune disorders, Perez-Alvarez et al. [44] found a lower rate of reactivation in patients who had antiviral prophylaxis $(23 \%$ vs. $62 \%$, $p=0.003)$ but a higher rate in those already treated with immunosuppressive drugs $(96 \%$ vs. $70 \%, p=0.033$ ).

In a national cohort of 3357 patients with IBD in the USA, Shah et al. did not identify a single case of confirmed clinically relevant HBVr after anti-TNF starting [45].

As regards HBsAg-negative/anti-HBc-positive subjects with IBD, only a few cases of $\mathrm{HBVr}$ have been described. Clarke et al. [46] investigated the prevalence of $\mathrm{HBVr}$ in a single-center retrospective cohort analysis of $120 \mathrm{HBsAg-negative/anti-HBc-positive}$ subjects (anti-TNF treatment in 19\% of the cases), and found a low rate of HBV reactivation $(0.8 \%)$. Solay et al. [47] assessed 29 cases of patients with resolved HBV infection who received biological treatment: $\mathrm{HBVr}$ was observed in five patients (17.2). Pauly et al. reported that not one of the $178 \mathrm{HBsAg}$-negative/anti-HBc-positive subjects treated with TNF antagonists had documented HBVr [22]. Additionally, Papa et al. [48] reported no 
cases of HBV reactivation in $22 \mathrm{HBsAg-negative/anti-HBc-positive} \mathrm{IBD} \mathrm{patients} \mathrm{treated}$ with anti-TNF. Additionally, no HBVr and/or associated biochemical breakthrough was detected in a retrospective study that evaluated 90 patients (of whom 13 with IBD) with past HBV infection who received anti-TNF treatment [49]. In the above-mentioned systematic review [44], the authors reported an HBVr rate of 39\% in HBsAg-positive patients and 5\% in HBsAg-negative/anti-HBc-positive patients.

In conclusion, complete serology for HBV is required in IBD patients to determine the virological status (active carrier, inactive carrier or anti-HBc positivity), since the HBV profile affects the choice of HBV therapy, prophylaxis, or monitoring. In fact, in consideration of the higher risk of reactivation, IBD patients who are HBsAg-positive carriers should receive prophylactic antiviral treatment with nucleotide or nucleoside analogues before the introduction steroids at moderate to high doses $(>20 \mathrm{mg} / \mathrm{die}$ of prednisone or equivalent) for more than 4 weeks, azathioprine, anti-TNF therapy, or ustekinumab. Treatment may be lifelong in patients with chronic HBV and for at least one year after discontinuing immunosuppressive therapy in HBsAg asymptomatic carriers.

The approach to IBD patients who are HBsAg-negative and anti-HBc-positive is not standardized across the various guidelines. The American Gastroenterological Association recommends antiviral prophylaxis for $\mathrm{HBsAg-negative/anti-HBc-positive} \mathrm{patients} \mathrm{treated}$ with anti-TNF or with corticosteroids (10-20 mg or $>20 \mathrm{mg}$ prednisone daily for 4 weeks); there is a moderate risk of reactivation in this population [32]. The European Association for the Study of the Liver [12] and the European Crohn and Colitis Organization guidelines [50] suggest the strategy of active monitoring of viremia and recommend that antiviral agents be initiated once HBV DNA or seroconversion to positive HBsAg is detected. Therefore, considering the indications of the published guidelines and the scant data available in the literature in support of antiviral prophylaxis, HBsAg monitoring every 2-3 months may be recommended for such patients.

\subsection{Risk of HBV Reactivation in Dermatological Diseases}

Immunosuppressive drugs, both conventional and biological, are used in many different dermatological diseases, among which psoriasis is the most common and affects approximately 125 million people worldwide [51]. Conventional disease modifying drugs (cDMARDs) include acitretine, cyclosporin A, and methotrexate; and biological DMARDs (bDMARDs) include etanercept, adalimumab, infliximab, ustekinumab, golimumab, certolizumab, and secukinumab. Trials investigating new drugs do not usually involve HBV patients, so data on their safety regarding HBV reactivation in patients with psoriasis are based mostly on case reports and small retrospective cohort studies.

Table 2 summarizes the studies evaluating reactivation of current and past HBV infections in the setting of dermatological disease.

Chiu et al. [52] evaluated the risk of reactivation of HBV in 14 psoriatic patients undergoing therapy with ustekinumab. Two out of the seven (29\%) HBsAg-positive patients not receiving prophylaxis showed HBVr during ustekinumab treatment, whereas no reactivation was observed among the $3 \mathrm{HBsAg}$-negative/ $\mathrm{HBcAb}$-positive patients.

In a retrospective cohort study, Ting et al. [53] included 54 subjects with active or previous infections. Only three patients experienced virological reactivation. The calculated incidence rate of annual HBV reactivation with ustekinumab was $17.4 \%$ among inactive HBV carriers without prophylaxis and $1.5 \%$ in the occult hepatitis B infection group.

A retrospective study by Snast et al. [54] reported no reactivation among 25 psoriatic patients with past infections and one with a current HBV infection treated with biological therapies. Similar results were observed in an Italian study among patients with psoriasis and chronic HBV infection treated with adalimumab [55].

In a cohort study published in 2018 [56], the authors followed-up 32 patients with psoriasis and concurrent positive HBV markers (chronic inactive and occult cases) treated with biological agents (adalimumab, etanercept, ustekinumab) for at least 24 weeks and found no evidence of viral reactivation 3 months after stopping treatment. 
Finally, a meta-analysis performed by Cantini et al. [57] estimated a pooled prevalence of $\mathrm{HBVr}$ of $3 \%$ among subjects with previous $\mathrm{HBV}$ infections, and of $15.4 \%$ in patients with overt infections during treatment with anti TNF for dermatological and rheumatological diseases.

Although the reliability of many of these studies is limited by small numbers of subjects and short periods of follow-up, the available evidence suggests that in HBsAgpositive patients who receive treatment with immunosuppressive drugs associated with moderate risk of HBV reactivation (anti-TNF $\alpha$, including etanercept, adalimumab, and golimumab; and cytokine or integrin inhibitors, such as ustekinumab or secukinumab), antiviral prophylaxis would be preferable; for HBsAg-negative/anti-HBc-positive patients, both antiviral prophylaxis and close monitoring with pre-emptive therapy are feasible options.

\subsection{Risk of Reactivation in Rheumatological Diseases}

Rheumatological drugs include corticosteroids, non-steroidal anti-inflammatory drugs (NSAIDs), analgesic drugs, and disease-modifying antirheumatic drugs (DMARDs). The latter are divided into conventional synthetics (cs) and biological (b) drugs.

The csDMARDs include sulfasalazine; methotrexate; hydroxychloroquine; leflunomide; and less frequently, azathioprine, gold salts, and minocycline [58]. The bDMARDs can instead be distinguished on the basis of mechanism of action into TNF inhibitors (etanercept, infliximab, adalimumab, certolizumab, and golimumab), IL-1 inhibitors (anakinra, and canakinumab), IL-6 and IL-6R inhibitors (tocilizumab and sarilumab, respectively), inhibitors of IL-17 (secukinumab and ixekizumab), IL-23 inhibitors (ustekinumab and guselkumab), and JAK kinase inhibitors (tofacitinib, baricitinib, upadacitinib, filgotinib, and peficitinib $[59,60]$.

Studies that provided data on HBVr in patients with rheumatological diseases are shown in Table 3. HBVr has been found in rheumatological patients receiving both csDMARD and bDMARD treatment. Among the csDMARDs, methotrexate has been widely used, but its impact on HBVr has not yet been clarified. A Thai study did not report episodes of reactivation among $65 \mathrm{HBcAb}$-positive, HbsAg-negative rheumatological patients treated for nine years with methotrexate [61], whereas seven cases of reactivation, five of which were severe, were described in the literature among patients with overt HBV infections treated with the same drug [62-66].

A study by Chen et al. [67] enrolling $123 \mathrm{HbsAg-positive} \mathrm{subjects} \mathrm{with} \mathrm{rheumatoid}$ arthritis from 2006 to 2012 demonstrated a higher risk of HBVr (occurring in 30 patients) when csDMARDS were combined with other immunosuppressants: in particular, lowdose glucocorticoids with csDMARDs and bDMARDs (excluding rituximab) caused an HBV reactivation in $54.5 \%$ of cases, bDMARDs (excluding rituximab) associated with cSDMARDs coincided with reactivation in $5.9 \%$ of patients, and the risk of $\mathrm{HBVr}$ for csDMARDs associated with glucocorticoids was $12.5 \%$. Regarding outcomes, despite antiviral treatment being initiated at the time of HBVr appearance, $13(43.3 \%)$ patients developed severe hepatitis and 5 (16.7\%) hepatic decompensation, with death in three cases.

As regards anti-TNF bDMARDs, a study by Ryu et al. [68] recorded two (6.9\%) cases of HBVr within one year of anti-TNF treatment among 29 patients not receiving a primary prophylaxis. Only one reactivation ( $9 \%$ ) was recorded in the prophylaxis group (20 patients) at the 64th week of therapy with bDMARDs.

Regarding HbsAg-negative patients, a prospective multicenter study by Fukuda et al. [69] described an HBVr rate of 1.93/100 people/year among 1042 patients undergoing immunosuppressive treatment for rheumatological diseases. The incidence of reactivation among patients testing negative for $\mathrm{HBsAb}$ was significantly higher than that of $\mathrm{HBsAb}$-positive subjects (4.32 vs. 1.42/100 persons/year). No liver dysfunction occurred during HBVr. In a subsequent paper on the same group, 57 cases of $\mathrm{HBVr}(0.43 / 100$ persons/year) occurred over the course of 4 years; age $>70$ years [70]. The presence of isolated anti-HBc 
antibodies and immunosuppressive therapy other than monotherapy with methotrexate were found to be independent risk factors for HBVr. The authors proposed a scoring system to distinguish between patients at higher and lower risks of reactivation. Finally, in a meta-analysis published in 2013, Lee et al. [71] reported eight (1.7\%) cases of HBV reactivation among 468 patients with previous HBV infections who underwent anti-TNF treatment for rheumatic disease.

In a study by Varisco et al. [72], HBVr was evaluated in patients with previous HBV infections treated with methotrexate plus rituximab (with or without steroids) for rheumatoid arthritis. None of the subjects received antiviral prophylaxis for HBV. No case of seroreversion to HbsAg positivity was observed, but 6 out of 28 (21\%) HBsAb-positive patients presented a decrease $(>50 \%)$ in the antibody titer. Only one patient was positive for HBV DNA after 6 months of treatment with rituximab; the subject was promptly treated with lamivudine, avoiding an exacerbation of hepatitis.

In a study by Urata et al. [73], $135 \mathrm{HBsAg-negative} \mathrm{and} \mathrm{anti-HBc-positive} \mathrm{patients}$ undergoing immunosuppressive treatment for rheumatoid arthritis were prospectively evaluated. HBV DNA was positive during follow-up in seven cases (5.1\%). The patients who received bDMARDs had a significantly higher rate of HBV reactivation compared with those who were treated with other immunosuppressants $(p=0.008)$, with a hazard ratio of 10.9 (1.4-87.7).

Nakamura et al. [74] evaluated 57 patients with rheumatoid arthritis treated with bDMARDs and a previous HBV infection, with a median observation of 18 months. No antiviral prophylaxis was prescribed. HBV DNA became positive in $5.3 \%$ of the population, specifically in two patients treated with tocilizumab and in one patient treated with etanercept. However, there were no significant changes in markers of liver function, and no patient required antiviral therapy.

Regarding the JAK kinase inhibitors, a study by Harigai et al. [75] included 215 patients with previous or current HBV infections, treated with baricitinib (with or without csDMARDs) for rheumatoid arthritis, in four clinical trials. All patients tested negative for HBV DNA at baseline. During the follow-up, 32 (14.9\%) patients tested positive for HBV DNA, but only four of them met the HBV reactivation criteria (HBV DNA $\geq 100 \mathrm{IU} / \mathrm{mL}$ ). The use of baricitinib was discontinued temporarily in two patients and permanently in four. In no case was there clinical evidence of hepatitis.

In conclusion, the risk of $\mathrm{HBVr}$ depends on the subject's immunosuppressive status and the baseline condition of HBV infection. For both HBsAg-positive and HBsAg-negative patients, the risk of $\mathrm{HBV}$ is low with csDMARDs, including methotrexate, leflunomide, and azathioprine; and short ( $<4$ weeks), low-dose $(<10 \mathrm{mg} /$ day of prednisone or equivalent) cortisone-based therapies. However, it is moderate with anti-TNFs (etanercept, infliximab, and adalimumab) or tyrosine kinase inhibitors (such as baricitinib), and is even higher with combination therapies; thus, an antiviral prophylaxis should be recommended in these cases $[18,76]$.

\subsection{Risk of HBV Reactivation in Neurological Diseases}

Multiple sclerosis (MS) is a chronic inflammatory disease of the central nervous system (CNS) causing demyelination, that causes progressive neurodegeneration and disability. Glucocorticoids have been widely used to manage the acute phases of the disease, although their effectiveness tends to decrease over time. However, disease modifying drugs acquired a central role in the treatment of MS outpatients. So far, a series of biological therapies have been approved which are distributed in the first, second, and third lines of treatment. All have some degree of immunosuppressive potential: they mainly include anti-CD20 monoclonal antibodies (ocrelizumab, ofatumumab), anti-CD52 antibodies (alemtuzumab), a4b1 integrin inhibitor (Natalizumab), DNA intercalator (Mitoxantrone), and sphingosine-1 phosphate inhibitor (fingolimod) and its modulators (siponimod, ozanimod) [77]. 
Table 1. Studies on HBV reactivation in patients with gastroenteric diseases.

\begin{tabular}{|c|c|c|c|c|c|c|c|c|c|}
\hline $\begin{array}{l}\text { First Author, Year } \\
\text { [Reference] }\end{array}$ & Study Design & N. Patients & $\begin{array}{l}\text { Gastroenteric } \\
\text { Disease }(n, \%)\end{array}$ & $\begin{array}{c}\text { Immunosuppressive } \\
\text { Treatment }\end{array}$ & HBV Status $(n, \%)$ & HBVr Definition & $\operatorname{HBVr}(n, \%)$ & $\begin{array}{l}\text { HBVr among Pts } \\
\quad \text { Receiving } \\
\text { Prophylaxis }(n, \%)\end{array}$ & $\begin{array}{l}\text { HBVr among Pts } \\
\text { Not Receiving } \\
\text { Prophylaxis }(n, \%)\end{array}$ \\
\hline Pauly MP, 2018 [22] & Retrospective & 8887 & 1186 (13.4) & $\begin{array}{c}\text { Anti-TNF } \alpha \\
\text { agents } \pm \text { steroids and } \\
\text { non-biological } \\
\text { immunosuppressants }\end{array}$ & $\begin{array}{c}\text { HBsAg+: } 23(0.3) \\
\text { HBsAg- } / \mathrm{HBcAb+:} \\
178(2)\end{array}$ & $\begin{array}{l}>1 \text { log increase in serum HBV } \\
\text { DNA from baseline OR serum } \\
\text { HBV DNA detectable when } \\
\text { previously undetectable OR HBV } \\
\text { DNA >2000 IU/mL if no baseline } \\
\text { OR reverse seroconversion from } \\
\text { HBsAg negative to HBsAg+. }\end{array}$ & $\begin{array}{c}\text { HBsAg+: } 9 \text { (39.1) } \\
\text { HBsAg-/HBcAb+: } \\
0(0)\end{array}$ & $\begin{array}{c}\text { HBsAg+: } 1(11.1) \\
\text { HBsAg-/HBcAb+: } \\
0(0)\end{array}$ & $\begin{array}{c}\text { HBsAg+: } 8(88.9) \\
\text { HBsAg-/HBcAb+: } \\
0(0)\end{array}$ \\
\hline Loras C, 2010 [42] & Retrospective & 162 & $162(100)$ & $\begin{array}{l}\text { Steroids } \pm \text { anti-TNF } \alpha \\
\text { agents } \pm \text { non-biological } \\
\text { immunosuppressants }\end{array}$ & $\begin{array}{c}\text { HBsAg+: } 25(15.4) \\
\text { HBsAg-/HBcAb+: } \\
65 \text { (40.1) }\end{array}$ & $\begin{array}{l}1.5-2 \text { fold the baseline value of } \\
\text { alanine transaminase (ALT) plus } \\
\text { an increase of }>2000 \mathrm{IU} / \mathrm{ml} \text { HBV } \\
\text { DNA levels or DNA reappearance } \\
\text { in a negative patient. }\end{array}$ & $\begin{array}{c}\text { HBsAg+: } 9(36) \\
\text { HBsAg-/ } / \mathrm{HBcAb+:} \\
0(0)\end{array}$ & $\begin{array}{c}\text { HBsAg+: } 1(11.1) \\
\text { HBsAg-/HBcAb+: } \\
0(0)\end{array}$ & $\begin{array}{c}\text { HBsAg+: } 8(88.9) \\
\text { HBsAg-/HBcAb+: } \\
0(0)\end{array}$ \\
\hline Morisco F, 2013 [43] & Retrospective & 5096 & $5096(100)$ & $\begin{array}{c}\text { Anti-TNF } \alpha \\
\text { agents } \pm \text { non-biological } \\
\text { immunosuppressants }\end{array}$ & $\begin{array}{c}\text { HBsAg+: } 6(0.1) \\
\text { HBsAg-/HBcAb+: } \\
4(0.07)\end{array}$ & $\begin{array}{l}\text { In HBsAg-positive patients }>1 \\
\text { log10 increase HBV DNA with or } \\
\text { without the concomitant increase } \\
\text { in transaminases; in isolated } \\
\text { anti-HBc-positive, the } \\
\text { re-emergence of HBsAg or } \\
\text { appearance or at least }>1 \text { log10 } \\
\text { increase HBV DNA }\end{array}$ & $\begin{array}{c}\text { HBsAg+: } 1(16.6) \\
\text { HBsAg-/HBcAb+: } \\
1 \text { (25) }\end{array}$ & $\begin{array}{c}\text { HBsAg+: } 0(0) \\
\text { HBsAg-/HBcAb+: } \\
0(0)\end{array}$ & $\begin{array}{c}\text { HBsAg+: } 1(100) \\
\text { HBsAg-/HBcAb+: } \\
0 \text { (0) }\end{array}$ \\
\hline $\begin{array}{l}\text { Perez-Alvarez, } \\
2011 \text { [44] }\end{array}$ & Retrospective & 257 & $20 *$ & Anti-TNF $\alpha$ agents & $\begin{array}{c}\text { HBsAg+: } 89 \text { (34.6) } \\
\text { HBsAg- / HBcAb+: } \\
168(65.3)\end{array}$ & $\begin{array}{l}\text { The reappearance of serum } \\
\text { HBV-DNA in a patient with } \\
\text { previously inactive or resolved } \\
\text { HBV infection, and either as an } \\
\text { increase of }>1 \text { log10 of viral load or } \\
>400 \mathrm{IU} / \mathrm{mL} \text { ( } 2000 \text { copies } / \mathrm{mL}) \\
\text { with respect to the baseline } \\
\text { HBV-DNA load before anti-TNF } \\
\text { therapy, or as the appearance of } \\
\text { serum HBV DNA above standard } \\
\text { cutoff values }(>60 \mathrm{IU} / \mathrm{L}, \\
\text { equivalent to }>300 \text { copies } / \mathrm{mL} \text { ) }\end{array}$ & $\begin{array}{c}\text { HBsAg+: } 35 \text { (39.3) } \\
\text { HBsAg-/HBcAb+: } \\
9 \text { (5.3) }\end{array}$ & $\begin{array}{c}\text { HBsAg+: } 7(20) \\
\text { HBsAg- / / } \mathrm{HBcAb+:} \\
0(0)\end{array}$ & $\begin{array}{c}\mathrm{HBsAg}+: 28(80)^{* *} \\
\mathrm{HBsAg}-/ \mathrm{HBCAb+:} \\
0(0)\end{array}$ \\
\hline Shah R, 2018 [45] & Retrospective & 3357 & $3357(100)$ & Anti-TNF $\alpha$ agents & $\begin{array}{c}\text { HBsAg+: NA } \\
\text { HBsAg-/HBcAb+: } \\
\text { NA }\end{array}$ & $\begin{array}{l}\text { Using ICD-9 codes for HBV } \\
(070.2 \times, 070.3 \times) \text {, acute liver failure } \\
(670 \times \times) \text {, or filled prescriptions for } \\
\text { medications used in the treatment } \\
\text { of HBV. Potential cases of HBV } \\
\text { reactivation were verified using } \\
\text { manual EMR through CAPRI. }\end{array}$ & $\begin{array}{c}\text { HBsAg+: } 0(0) \\
\text { HBsAg-/HBcAb+: } \\
0(0)\end{array}$ & $\begin{array}{c}\text { HBsAg+: } 0(0) \\
\text { HBsAg-/HBcAb+: } \\
0(0)\end{array}$ & $\begin{array}{c}\text { HBsAg+: } 0(0) \\
\text { HBsAg-/HBcAb+: } \\
0(0)\end{array}$ \\
\hline Clarke WT, 2018 [46] & Retrospective & 3171 & $23^{* * *}$ & $\begin{array}{l}\text { Anti-TNF } \alpha \text { agents } \pm \\
\text { immunomodulators }\end{array}$ & $\begin{array}{c}\text { HBsAg+: NA } \\
\text { HBsAg-/HBcAb+: } \\
120(3.8)\end{array}$ & $\begin{array}{l}\text { Demonstration of reverse } \\
\text { seroconversion to positive HBsAg } \\
\text { status OR development of } \\
\text { detectable HBV DNA }\end{array}$ & $\begin{array}{c}\mathrm{HBsAg}+\mathrm{NA} \\
\mathrm{HBsAg}-/ \mathrm{HBcAb}+: \\
1(0.8)\end{array}$ & $\begin{array}{c}\mathrm{HBsAg+:} \mathrm{NA} \\
\mathrm{HBsAg}-/ \mathrm{HBcAb}+: \\
\text { NA }\end{array}$ & $\begin{array}{c}\text { HBsAg+: NA } \\
\text { HBsAg-/HBcAb+:NA }\end{array}$ \\
\hline
\end{tabular}


Table 1. Cont.

\begin{tabular}{|c|c|c|c|c|c|c|c|c|c|}
\hline $\begin{array}{l}\text { First Author, Year } \\
\text { [Reference] }\end{array}$ & Study Design & N. Patients & $\begin{array}{l}\text { Gastroenteric } \\
\text { Disease }(n, \%)\end{array}$ & $\begin{array}{l}\text { Immunosuppressive } \\
\text { Treatment }\end{array}$ & HBV Status $(n, \%)$ & HBVr Definition & $\operatorname{HBVr}(n, \%)$ & $\begin{array}{l}\text { HBVr among Pts } \\
\text { Receiving } \\
\text { Prophylaxis }(n, \%)\end{array}$ & $\begin{array}{l}\text { HBVr among Pts } \\
\text { Not Receiving } \\
\text { Prophylaxis }(n, \%)\end{array}$ \\
\hline Solay AH, 2018 [47] & Retrospective & 278 & $1 * * * *$ & Anti-TNF $\alpha$ agents & $\begin{array}{c}\text { HBsAg+: NA } \\
\mathrm{HBsAg}-/ \mathrm{HBcAb}+: \\
29\end{array}$ & $\begin{array}{l}\text { Detection of HBV DNA and/or } \\
\text { HBsAg conversion in blood } \\
\text { analysis during the follow-up. }\end{array}$ & $\begin{array}{c}\text { HBsAg+: NA } \\
\text { HBsAg-/HBcAb+: } \\
5 \text { (17.2) }\end{array}$ & $\begin{array}{c}\text { HBsAg+: NA } \\
\text { HBsAg-/HBcAb+: } \\
0(0)\end{array}$ & $\begin{array}{c}\text { HBsAg+: NA } \\
\text { HBsAg-/HBcAb+: } \\
0(0)\end{array}$ \\
\hline Papa A, 2013 [48] & Prospective & 301 & $301(100)$ & Anti-TNF $\alpha$ agents & $\begin{array}{c}\mathrm{HBsAg}+: 1(0.3) \\
\mathrm{HBsAg}-/ \mathrm{HBcAb}+: \\
22(7.3)\end{array}$ & $\begin{array}{l}\text { HBsAg or HBV-DNA detection in } \\
\text { patients previously negative for } \\
\text { HBsAg or with undetectable levels } \\
\text { of HBV DNA }\end{array}$ & $\begin{array}{c}\text { HBsAg+: } 0(0) \\
\text { HBsAg-/HBcAb+: } \\
0(0)\end{array}$ & $\begin{array}{l}\text { HBsAg+: } 0(0) \\
\text { HBsAg-/HBcAb+: } \\
\text { NA }\end{array}$ & $\begin{array}{l}\text { HBsAg+: } 0(0) \\
\text { HBsAg-/HBcAb+: } \\
\text { NA }\end{array}$ \\
\hline Sayar S, 2020 [49] & Retrospective & 653 & $13^{* * * * *}$ & $\begin{array}{c}\text { Anti-TNF } \alpha \\
\text { agents } \pm \text { corticosteroid } \\
\text { and/or } \\
\text { immunomodulator. }\end{array}$ & $\begin{array}{l}\mathrm{HBsAg}+: 5(0.8) \\
\mathrm{HBsAg}-/ \mathrm{HBcAb+:} \\
90(13.8)\end{array}$ & $\begin{array}{l}\text { An increase of }>1 \log 10 \mathrm{IU} / \mathrm{mL} \text { in } \\
\text { the HBV DNA level compared } \\
\text { with the past value OR positivity } \\
\text { in those who were HBV DNA } \\
\text { negative OR detection of any } \\
\text { positive HBV DNA level in } \\
\text { patients whose baseline HBV DNA } \\
\text { level was not studied }\end{array}$ & $\begin{array}{c}\text { HBsAg+: NA } \\
\text { HBsAg-/HBcAb+: } \\
0(0)\end{array}$ & $\begin{array}{c}\text { HBsAg+: NA } \\
\mathrm{HBsAg}-/ \mathrm{HBcAb+} \\
0(0)\end{array}$ & $\begin{array}{c}\text { HBsAg+: NA } \\
\text { HBsAg-/HBcAb+: } \\
0(0)\end{array}$ \\
\hline
\end{tabular}

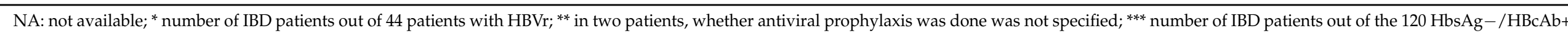
patients; **** number of IBD patients out of the $29 \mathrm{HbsAg}-/ \mathrm{HBcAb}+$ patients; ***** number of IBD patients out of the $90 \mathrm{HbsAg}-/ \mathrm{HBcAb}+$ patients.

Table 2. Studies on HBV reactivation in patients with dermatological diseases.

\begin{tabular}{|c|c|c|c|c|c|c|c|c|c|}
\hline $\begin{array}{l}\text { First Author, Year } \\
\text { [Reference] }\end{array}$ & Study Design & N. Patients & $\begin{array}{l}\text { Dermatological } \\
\text { Disease }\end{array}$ & $\begin{array}{c}\text { Immunosuppressive } \\
\text { Treatment }\end{array}$ & HBV Status $(n, \%)$ & HBVr Definition & $\operatorname{HBVr}(n, \%)$ & $\begin{array}{c}\text { HBVr among Pts } \\
\text { Receiving } \\
\text { Prophylaxis }(n, \%)\end{array}$ & $\begin{array}{c}\text { HBVr among Pts } \\
\text { Not Receiving } \\
\text { Prophylaxis }(n, \%)\end{array}$ \\
\hline Chiu, 2013 [52] & $\begin{array}{l}\text { Retrospective } \\
\text { cohort }\end{array}$ & 14 & Psoriasis & Ustekinumab & $\begin{array}{c}\text { HBsAg+: } 11 \\
\mathrm{HBsAg}-/ \mathrm{HBcAb+:} \\
3\end{array}$ & $\begin{array}{l}\text { One of the following: } 1 \text {. ALT } \\
\text { elevation with increase in serum } \\
\text { HBV DNA level to }>1 \text { log10 } \\
\text { copies / mL higher than before } \\
\text { therapy; } 2 \text {. Absolute increase in } \\
\text { HBV DNA level exceeding } 6 \text { log10 } \\
\text { copies /mL; 3. Conversion of } \\
\text { serum HBV-DNA test results from } \\
\text { negative to positive. }\end{array}$ & $\begin{array}{c}\text { HBsAg+: } 2(14.3) \\
\text { HBsAg-/HBcAb+: } \\
0(0)\end{array}$ & $\begin{array}{c}\text { HBsAg+: } 0(0) \\
\text { HBsAg-/HBcAb+:0 } \\
(0)\end{array}$ & $\begin{array}{c}\text { HBsAg+: } 2(28.6) \\
\text { HBsAg-/HBcAb+:0 } \\
\text { (0) }\end{array}$ \\
\hline
\end{tabular}


Table 2. Cont.

\begin{tabular}{|c|c|c|c|c|c|c|c|c|c|}
\hline $\begin{array}{l}\text { First Author, Year } \\
\text { [Reference] }\end{array}$ & Study Design & N. Patients & $\begin{array}{l}\text { Dermatological } \\
\text { Disease }\end{array}$ & $\begin{array}{c}\text { Immunosuppressive } \\
\text { Treatment }\end{array}$ & HBV Status ( $n, \%)$ & HBVr Definition & $\operatorname{HBVr}(n, \%)$ & $\begin{array}{l}\text { HBVr among Pts } \\
\text { Receiving } \\
\text { Prophylaxis }(n, \%)\end{array}$ & $\begin{array}{c}\text { HBVr among Pts } \\
\text { Not Receiving } \\
\text { Prophylaxis }(n, \%)\end{array}$ \\
\hline Snast, 2017 [54] & $\begin{array}{l}\text { Retrospective } \\
\text { cohort }\end{array}$ & 26 & Psoriasis & $\begin{array}{l}\text { Adalimumab, Etanercept, } \\
\text { Golimumab, Infliximab, } \\
\text { Secukinumab, } \\
\text { Ustekinumab }\end{array}$ & $\begin{array}{c}\mathrm{HBsAg+:}: 1 \\
\mathrm{HBsAg}-/ \mathrm{HBcAb+:} \\
26\end{array}$ & $\begin{array}{l}\text { One of the following: } \\
\text { 1. Increase in HBV replication of at } \\
\text { least } 1 \log 10 \text { copies } / \mathrm{mL} \\
\text { 2. Conversion of serum HBV DNA } \\
\text { results from negative to positive }\end{array}$ & $\begin{array}{c}\text { HBsAg+: } 0(0) \\
\text { HBsAg-/HBcAb+: } \\
0(0)\end{array}$ & $\begin{array}{c}\text { HBsAg+: } 0(0) \\
\text { HBsAg-/HBcAb+: } \\
0(0)\end{array}$ & $\begin{array}{c}\text { HBsAg+: } 0(0) \\
\text { HBsAg- } / \text { HBcAb+: } \\
0(0)\end{array}$ \\
\hline Piaserico, 2017 [55] & $\begin{array}{l}\text { Retrospective } \\
\text { cohort }\end{array}$ & 17 & Psoriasis & Adalimumab & $\begin{array}{c}\text { HBsAg+: } 10 \\
\text { HBsAg-/HBcAb+: } \\
\quad 7\end{array}$ & $\begin{array}{l}\text { One of the following: } \\
\text { 1. ALT elevation with increase in } \\
\text { serum HBV DNA level to }>1 \text { log10 } \\
\text { copies / mL higher } \\
\text { than before therapy; } \\
\text { 2. Absolute increase in HBV DNA } \\
\text { level exceeding } \\
6 \text { log10 copies / mL; } \\
\text { 3. Conversion of serum HBV-DNA } \\
\text { test results from negative to } \\
\text { positive. }\end{array}$ & $\begin{array}{c}\text { HBsAg+: } 0(0) \\
\text { HBsAg-/HBcAb+: } \\
0(0)\end{array}$ & HBsAg+: $0(0)$ & $\begin{array}{c}\text { HBsAg+: } 0(0) \\
\text { HBsAg-/HBcAb+: } \\
0(0)\end{array}$ \\
\hline AlMutairi, 2018 [56] & $\begin{array}{l}\text { Prospective } \\
\text { cohort }\end{array}$ & 32 & Psoriasis & $\begin{array}{l}\text { Adalimumab, Etanercept, } \\
\text { Ustekinumab }\end{array}$ & $\begin{array}{c}\mathrm{HBsAg+:} 4 \\
\mathrm{HBsAg}-/ \mathrm{HBcAb+:} \\
28\end{array}$ & $\begin{array}{l}\text { One of the following: } \\
\text { 1. Increase in serum HBV DNA } \\
\text { level to > } 1 \text { log10 copies } / \mathrm{mL} \text { higher } \\
\text { than before therapy; } \\
\text { 2. Absolute increase in HBV DNA } \\
\text { level exceeding } \\
6 \text { log10 copies / mL; } \\
\text { 3. Conversion of serum HBV-DNA } \\
\text { test results from negative to } \\
\text { positive. }\end{array}$ & $\begin{array}{c}\text { HBsAg+: } 0(0) \\
\text { HBsAg-/HBcAb+: } \\
0(0)\end{array}$ & $\begin{array}{c}\mathrm{HBsAg}-/ \mathrm{HBcAb}+: \\
0(0)\end{array}$ & HBsAg+: $0(0)$ \\
\hline
\end{tabular}

Table 3. Studies on HBV reactivation in patients with rheumatological diseases.

\begin{tabular}{|c|c|c|c|c|c|c|c|c|c|}
\hline $\begin{array}{l}\text { First Author, Year } \\
\text { [Reference] }\end{array}$ & Study Design & N. Patients & $\begin{array}{l}\text { Rheumatological } \\
\text { Disease }\end{array}$ & $\begin{array}{c}\text { Immunosuppressive } \\
\text { Treatment }\end{array}$ & HBV Status $(n, \%)$ & HBVr Definition & $\operatorname{HBVr}(n, \%)$ & $\begin{array}{l}\text { HBVr among Pts } \\
\text { Receiving } \\
\text { Prophylaxis }(n, \%)\end{array}$ & $\begin{array}{l}\text { HBVr among Pts } \\
\text { Not Receiving } \\
\text { Prophylaxis }(n, \%)\end{array}$ \\
\hline $\begin{array}{l}\text { Laohapand, } \\
\text { 2015 [61] }\end{array}$ & Cross-sectional & 173 & $\begin{array}{l}\text { RA, spondy- } \\
\text { loarthropathies, } \\
\text { systemic lupus } \\
\text { erythematosus, } \\
\text { others }\end{array}$ & Methotrexate & $\begin{array}{c}\text { HBsAg+: } 1 \text { (0.6) } \\
\text { HBsAg-/HBcAb+: } \\
65 \text { (37.6) }\end{array}$ & Not reported & $\begin{array}{c}\text { HBsAg+: } 0(0) \\
\text { HBsAg-/HBcAb+: } \\
0(0)\end{array}$ & & $\begin{array}{c}\text { HBsAg+: } 0(0) \\
\text { HBsAg-/HBcAb+: } \\
\text { (0) }\end{array}$ \\
\hline Chen, 2017 [67] & $\begin{array}{l}\text { Retrospective } \\
\text { cohort }\end{array}$ & 123 & RA & $\begin{array}{l}\text { Glucocorticoids: } 51(41.5) \\
\text { bDMARDS: } 36(29.3) \\
\text { csDMARDs: } 123(100)\end{array}$ & HBsAg+: 123 (100) & $\begin{array}{l}\text { One of the following: } \\
\text { 1. Increase in HBV DNA } \\
>1 \text { Log10 IU / mL compared } \\
\text { with baseline } \\
\text { 2. 3-fold increase in serum alanine } \\
\text { aminotransferase (ALT) level } \\
\text { accompanied by HBV DNA } \\
>20,000 \text { copies } / \mathrm{mL}\end{array}$ & HBsAg+: 30 (24.4) & & HBsAg+: 30 (24.4) \\
\hline
\end{tabular}


Table 3. Cont.

\begin{tabular}{|c|c|c|c|c|c|c|c|c|c|}
\hline $\begin{array}{l}\text { First Author, Year } \\
\text { [Reference] }\end{array}$ & Study Design & N. Patients & $\begin{array}{l}\text { Rheumatological } \\
\text { Disease }\end{array}$ & $\begin{array}{c}\text { Immunosuppressive } \\
\text { Treatment }\end{array}$ & HBV Status $(n, \%)$ & HBVr Definition & $\operatorname{HBVr}(n, \%)$ & $\begin{array}{l}\text { HBVr among Pts } \\
\text { Receiving } \\
\text { Prophylaxis }(n, \%)\end{array}$ & $\begin{array}{c}\text { HBVr among Pts } \\
\text { Not Receiving } \\
\text { Prophylaxis }(n, \%)\end{array}$ \\
\hline Ryu, 2012 [68] & $\begin{array}{l}\text { Retrospective } \\
\text { cohort }\end{array}$ & 49 & $\begin{array}{l}\text { RA, ankylosing } \\
\text { spondylitis }\end{array}$ & $\begin{array}{l}\text { Etanercept, Infliximab, } \\
\text { adalimumab }\end{array}$ & HBsAg+: 49 (100) & $\begin{array}{c}\text { Both the following: } \\
\text { 1. 10-fold rise in HBV DNA } \\
\text { compared with baseline resulting } \\
\text { in HBV DNA greater than } \\
\text { 20,000 IU/mL (HBeAg-positive } \\
\text { patients) or 2000 IU/mL } \\
\text { (HBeAg-negative patients), } \\
\text { 2. Increase in AST or ALT to above } \\
\text { twice the upper normal limit } \\
\text { (40 IU /l) }\end{array}$ & HBsAg+: 3 (6.1) & HBsAg+: 1 (5.0) & $\mathrm{HBsAg}+: 2(6.9)$ \\
\hline Fukuda, $2019[70]$ & $\begin{array}{l}\text { Prospective } \\
\text { cohort }\end{array}$ & 1127 & RA, others & $\begin{array}{c}\text { Glucocorticoids: } \\
373 \text { (38.9) bDMARDS: } \\
274 \text { (28.8) csDMARDs: } \\
751 \text { (79.1) }\end{array}$ & $\begin{array}{l}\mathrm{HBsAg}-/ \mathrm{HBcAb}+: \\
\quad 1127(100)\end{array}$ & Positive conversion of HBV-DNA & $\begin{array}{l}\mathrm{HBsAg}-/ \mathrm{HBcAb}+: \\
57(5.1)\end{array}$ & & $\begin{array}{l}\mathrm{HBsAg}-/ \mathrm{HBcAb}+: \\
57(5.1)\end{array}$ \\
\hline Varisco, 2016 [72] & $\begin{array}{l}\text { Retrospective } \\
\text { cohort }\end{array}$ & 33 & RA & Rituximab \pm DMSARDs & $\begin{array}{l}\mathrm{HBsAg}-/ \mathrm{HBcAb+:} \\
33(100)\end{array}$ & $\begin{array}{l}\text { HBsAg seroreversion or serum } \\
\text { HBV-DNA positivity }\end{array}$ & $\begin{array}{c}\mathrm{HBsAg}-/ \mathrm{HBcAb}+: \\
0(0)\end{array}$ & & $\begin{array}{c}\mathrm{HBsAg}-/ \mathrm{HBcAb}+\mathrm{:} \\
0(0)\end{array}$ \\
\hline Urata, $2011[73]$ & $\begin{array}{l}\text { Prospective } \\
\text { cohort }\end{array}$ & 123 & RA & $\begin{array}{l}\text { Glucocorticoids, } \\
\text { bDMARDS, csDMARDs }\end{array}$ & $\begin{array}{l}\text { HBsAg-/HBcAb+: } \\
123(100)\end{array}$ & Not reported & $\begin{array}{c}\mathrm{HBsAg}-/ \mathrm{HBcAb}+: \\
7(5.2)\end{array}$ & & $\begin{array}{c}\mathrm{HBsAg}-/ \mathrm{HBcAb}+: \\
7(5.2)\end{array}$ \\
\hline Nakamura, 2016 [74] & $\begin{array}{c}\text { Retrospective } \\
\text { cohort }\end{array}$ & 57 & RA & bDMARDs & $\begin{array}{c}\text { HBsAg-/HBcAb+: } \\
57(100)\end{array}$ & Serum HBV-DNA positivity & $\begin{array}{c}\text { HBsAg-/HBcAb+: } \\
3(5.3) \\
\end{array}$ & & $\begin{array}{c}\mathrm{HBsAg}-/ \mathrm{HBcAb}+: \\
3(5.3)\end{array}$ \\
\hline
\end{tabular}

Footnotes: RA: rheumatoid arthritis. 
Although all these drugs seem to be related to $\mathrm{HBVr}$, limited data are available in the literature concerning the risk of HBVr when used in a neurological setting. Ciardi et al. [78] reported a case of HBVr in a patient with a previous HBV infection treated with ocrelizumab for multiple sclerosis who did not receive prophylaxis. Although many authors agree on the need for antiviral prophylaxis in patients treated with ocrelizumab, similarly to what is recommended for other anti-CD20 antibodies, no clear and definitive consensus exists on the best prevention strategies in subjects receiving other immunosuppressive drugs in this setting [79]. Further studies are needed to clarify this point.

\subsection{Risk of HBV Reactivation in COVID-19 Patients}

The SARS-CoV-2 pandemic has been responsible for more than 150 million cases and over 3 million deaths as of April 2021, according to the data reported on the online dashboard implemented by the Johns Hopkins University [80]. Several immunosuppressive and immunomodulating agents have been adopted for the treatment of COVID-19, such as corticosteroids, which are currently recommended by the WHO guidelines for severe or critical diseases [81], and interleukin-6 (IL-6) inhibitors, which have been tested in several clinical trials compared to the standard of care [82].

As already stated, high dose glucocorticoids significantly increase the risk of reactivation in both overt and occult B infections [18]. However, limited data are available in the literature on the HBVr rate of COVID-19 patients treated with corticosteroids. A retrospective study reported three cases of $\mathrm{HBVr}$, two of whom had received methylprednisolone treatment, among 20 Chinese HBsAg-positive, treatment-naïve patients hospitalized for SARS-CoV-2 pneumonia between January and March 2020 [83].

Regarding the IL-6 inhibitors, several studies have reported an increased risk of $\mathrm{HBVr}$ in patients receiving tocilizumab for rheumatological diseases [84]. However, a retrospective cohort study [85] including $29 \mathrm{HBsAg-negative/anti-HBc-positive} \mathrm{patients} \mathrm{receiving}$ immunosuppressive treatment for COVID-19 (mostly tocilizumab or siltuximab) reported no case of $\mathrm{HBVr}$ requiring antiviral treatment. Only two patients showed detectable HBV DNA during the follow-up, in both cases below the limit of quantification $(<15 \mathrm{UI} / \mathrm{mL})$. Most probably, the short duration of treatment limits the risk of reactivation in this setting. No data are available on the risks related to other immunosuppressive agents that have been used in COVID-19 patients, such as baricitinib, ruxolitinib, and tofacitinib; however, these drugs have been associated with significant risks of HBVr reactivation in other settings [75]. Therefore, all patients expected to be treated with corticosteroids for more than 7-10 days or with other immunosuppressive drugs for COVID-19 pneumonia should be screened for current and previous HBV infections, in order to evaluate the risk of reactivation and implement preventive strategies when needed.

\section{Conclusions}

The growing use of immunosuppressive treatments in patients with a large variety of non-oncological diseases has drawn attention to the risk of reactivation of HBV infection in many settings. However, the available data on the risk of HBVr related to the different drugs are limited and fragmentary. Further prospective studies are needed to assess the best preventive strategies to reduce the occurrence of these potentially life-threatening events.

Author Contributions: L.O., M.P., and N.C. were involved in conceptualization and design, and drafting of the manuscript; C.C., P.G., A.V.C., and F.C. were involved in acquisition of data, analysis and interpretation of data, and critical revision of the manuscript. All authors have read and agreed to the published version of the manuscript.

Funding: This research received no external funding.

Institutional Review Board Statement: Not applicable.

Informed Consent Statement: Not applicable. 
Conflicts of Interest: The authors declare no conflict of interest.

\section{References}

1. Stone, G.M.; Mullin, S.A.; Teran, A.A.; Hallinan, D.T., Jr.; Minor, A.M.; Hexemer, A.; Balsara, N.P. Resolution of the Modulus versus Adhesion Dilemma in Solid Polymer Electrolytes for Rechargeable Lithium Metal Batteries. J. Electrochem. Soc. 2012, 159, A222-A227. [CrossRef]

2. Raimondo, G.; Locarnini, S.; Pollicino, T.; Levrero, M.; Zoulim, F.; Lok, A.S.; Allain, J.-P.; Berg, T.; Bertoletti, A.; Brunetto, M.R.; et al. Update of the Statements on Biology and Clinical Impact of Occult Hepatitis B Virus Infection. J. Hepatol. 2019, 71, 397-408. [CrossRef]

3. Pisaturo, M.; Onorato, L.; Russo, A.; Chiodini, P.; Coppola, N. An Estimation of the Prevalence of Occult HBV Infection in Western Europe and in Northern America: A Meta-Analysis. J. Viral Hepat. 2020, 27, 415-427. [CrossRef] [PubMed]

4. Loomba, R.; Liang, T.J. Hepatitis B Reactivation Associated with Immune Suppressive and Biological Modifier Therapies: Current Concepts, Management Strategies, and Future Directions. Gastroenterology 2017, 152, 1297-1309. [CrossRef] [PubMed]

5. Wang, B.; Mufti, G.; Agarwal, K. Reactivation of Hepatitis B Virus Infection in Patients with Hematologic Disorders. Haematologica 2019, 104, 435-443. [CrossRef]

6. Sagnelli, C.; Pisaturo, M.; Calò, F.; Martini, S.; Sagnelli, E.; Coppola, N. Reactivation of Hepatitis B Virus Infection in Patients with Hemo-Lymphoproliferative Diseases, and its Prevention. World J. Gastroenterol. 2019, 25, 3299-3312. [CrossRef] [PubMed]

7. Fattovich, G. Natural History and Prognosis of Hepatitis B. Semin. Liver Dis. 2003, 23, 47-58. [CrossRef] [PubMed]

8. World Health Organization. Hepatitis C. Available online: https://www.who.int/en/news-room/fact-sheets/detail/hepatitis-c (accessed on 4 March 2019).

9. Coppola, N.; Monari, C.; Alessio, L.; Onorato, L.; Gualdieri, L.; Sagnelli, C.; Minichini, C.; Sagnelli, E.; Di Caprio, G.; Surace, L.; et al. Blood-borne Chronic Viral Infections in a Large Cohort of Immigrants in Southern Italy: A Seven-Centre, Prospective, Screening Study. Travel Med. Infect. Dis. 2020, 35, 101551. [CrossRef] [PubMed]

10. van Houdt, R.; Bruisten, S.M.; Speksnijder, A.G.; Prins, M. Unexpectedly High Proportion of Drug Users and Men Having Sex with Men who Develop Chronic Hepatitis B Infection. J. Hepatol. 2012, 57, 529-533. [CrossRef] [PubMed]

11. WHO. Global Health Sector Strategy on Viral Hepatitis 2016-2021 Towards Ending Viral Hepatitis. 2017. Available online: https:/ / apps.who.int/iris/bitstream/handle/10665/246177/WHO-HIV-2016.06-eng.pdf? sequence=1\&isAllowed=y (accessed on 28 October 2021).

12. Lampertico, P.; Agarwal, K.; Berg, T.; Buti, M.; Janssen, H.L.; Papatheodoridis, G.; Zoulim, F.; Tacke, F. EASL 2017 Clinical Practice Guidelines on the Management of Hepatitis B Virus Infection. J. Hepatol. 2017, 67, 370-398. [CrossRef] [PubMed]

13. Coppola, N.; Onorato, L.; Pisaturo, M.; Macera, M.; Sagnelli, C.; Martini, S.; Sagnelli, E. Role of Occult Hepatitis B Virus Infection in Chronic Hepatitis C. World J. Gastroenterol. 2015, 21, 11931-11940. [CrossRef]

14. Coppola, N.; Onorato, L.; Sagnelli, C.; Sagnelli, E.; Angelillo, I.F. Association Between Anti-HBc Positivity and Hepatocellular Carcinoma in HBsAg-negative Subjects with Chronic Liver Disease: A Meta-Analysis. Medicine 2016, 95, e4311. [CrossRef] [PubMed]

15. Di Marco, V.; Iacono, O.L.; Camma, C.; Vaccaro, A.; Giunta, M.; Martorana, G.; Fuschi, P.; Almasio, P.L.; Craxi, A. The Long-Term Course of Chronic Hepatitis B. Hepatology 1999, 30, 257-264. [CrossRef]

16. Fattovich, G.; Brollo, L.; Giustina, G.; Noventa, F.; Pontisso, P.; Alberti, A.; Realdi, G.; Ruol, A. Natural History and Prognostic Factors for Chronic Hepatitis Type B. Gut 1991, 32, 294-298. [CrossRef] [PubMed]

17. Fattovich, G.; Bortolotti, F.; Donato, F. Natural History of Chronic Hepatitis B: Special Emphasis on Disease Progression and Prognostic Factors. J. Hepatol. 2008, 48, 335-352. [CrossRef] [PubMed]

18. Perrillo, R.P.; Gish, R.; Falck-Ytter, Y.T. American Gastroenterological Association Institute Technical Review on Prevention and Treatment of Hepatitis B Virus Reactivation During Immunosuppressive Drug Therapy. Gastroenterology 2015, 148, 221-244.e3. [CrossRef] [PubMed]

19. Shi, Y.; Zheng, M. Hepatitis B Virus Persistence and Reactivation. BMJ 2020, 370. [CrossRef] [PubMed]

20. Paul, S.; Saxena, A.P.; Terrin, N.; Viveiros, K.; Balk, E.M.; Wong, J.B. Hepatitis B Virus Reactivation and Prophylaxis during Solid Tumor Chemotherapy. Ann. Intern. Med. 2016, 164, 30-40. [CrossRef] [PubMed]

21. Chen, Y.-H.; Huang, W.-N.; Wu, Y.-D.; Lin, C.-T.; Chen, D.-Y.; Hsieh, T.-Y. Reactivation of Hepatitis B Virus Infection in Patients with Rheumatoid Arthritis Receiving Tofacitinib: A Real-World Study. Ann. Rheum. Dis. 2018, 77, 780-782. [CrossRef] [PubMed]

22. Pauly, M.P.; Tucker, L.-Y.; Szpakowski, J.-L.; Ready, J.B.; Baer, D.; Hwang, J.; Lok, A.S.-F. Incidence of Hepatitis B Virus Reactivation and Hepatotoxicity in Patients Receiving Long-term Treatment with Tumor Necrosis Factor Antagonists. Clin. Gastroenterol. Hepatol. 2018, 16, 1964-1973.e1. [CrossRef] [PubMed]

23. Seto, W.-K.; Chan, T.S.; Hwang, Y.-Y.; Wong, D.K.-H.; Fung, J.; Liu, K.S.-H.; Gill, H.; Lam, Y.-F.; Lie, A.K.; Lai, C.-L.; et al. Hepatitis B Reactivation in Patients with Previous Hepatitis B Virus Exposure Undergoing Rituximab-Containing Chemotherapy for Lymphoma: A Prospective Study. J. Clin. Oncol. 2014, 32, 3736-3743. [CrossRef] [PubMed]

24. Yeo, W.; Chan, P.K.; Zhong, S.; Ho, W.M.; Steinberg, J.L.; Tam, J.S.; Hui, P.; Leung, N.W.; Zee, B.; Johnson, P.J. Frequency of Hepatitis B Virus Reactivation in Cancer Patients Undergoing Cytotoxic Chemotherapy: A Prospective Study of 626 Patients with Identification of Risk Factors. J. Med. Virol. 2000, 62, 299-307. [CrossRef] 
25. Yeo, W.; Zee, B.C.-Y.; Zhong, S.; Chan, P.; Wong, W.-L.; Ho, W.M.; Lam, K.C.; Johnson, P.J. Comprehensive Analysis of Risk Factors Associating with Hepatitis B Virus (HBV) Reactivation in Cancer Patients Undergoing Cytotoxic Chemotherapy. Br. J. Cancer 2004, 90, 1306-1311. [CrossRef]

26. Pisaturo, M.; Di Caprio, G.; Calò, F.; Portunato, F.; Martini, S.; Coppola, N. Management of HBV Reactivation in Non-Oncological Patients. Expert Rev. Anti-Infect. Ther. 2018, 16, 611-624. [CrossRef]

27. Smalls, D.J.; Kiger, R.E.; Norris, L.B.; Bennett, C.L.; Love, B.L. Hepatitis B Virus Reactivation: Risk Factors and Current Management Strategies. Pharmacother. J. Hum. Pharmacol. Drug Ther. 2019, 39, 1190-1203. [CrossRef]

28. Mozessohn, L.; Chan, K.K.W.; Feld, J.J.; Hicks, L.K. Hepatitis B Reactivation in HBsAg-Negative/HBcAb-Positive Patients Receiving Rituximab for Lymphoma: A Meta-Analysis. J. Viral Hepat. 2015, 22, 842-849. [CrossRef]

29. Tur-Kaspa, R.; Burk, R.D.; Shaul, Y.; Shafritz, D.A. Hepatitis B Virus DNA Contains a Glucocorticoid-Responsive Element. Proc. Natl. Acad. Sci. USA 1986, 83, 1627-1631. [CrossRef] [PubMed]

30. Navarro, R.; Vilarrasa, E.; Herranz, P.; Puig, L.; Bordas, X.; Carrascosa, J.; Taberner, R.; Ferrán, M.; García-Bustinduy, M.; Romero-Maté, A.; et al. Safety and Effectiveness of Ustekinumab and Antitumour Necrosis Factor Therapy in Patients with Psoriasis and Chronic Viral Hepatitis B or C: A Retrospective, Multicentre Study in a Clinical Setting. Br. J. Dermatol. 2013, 168, 609-616. [CrossRef] [PubMed]

31. Orlandi, E.M.; Elena, C.; Bono, E. Risk of Hepatitis B Reactivation under Treatment with Tyrosine-Kinase Inhibitors for Chronic Myeloid Leukemia. Leuk. Lymphoma 2017, 58, 1764-1766. [CrossRef] [PubMed]

32. Reddy, K.R.; Beavers, K.L.; Hammond, S.; Lim, J.K.; Falck-Ytter, Y.T. American Gastroenterological Association Institute Guideline on the Prevention and Treatment of Hepatitis B Virus Reactivation during Immunosuppressive Drug Therapy. Gastroenterology 2015, 148, 215-219. [CrossRef]

33. Brost, S.; Schnitzler, P.; Stremmel, W.; Eisenbach, C. Entecavir as Treatment for Reactivation of Hepatitis B in Immunosuppressed Patients. World J. Gastroenterol. 2010, 16, 5447-5451. [CrossRef] [PubMed]

34. Chen, F.W.; Coyle, L.; Jones, B.E.; Pattullo, V. Entecavir Versus Lamivudine for Hepatitis B Prophylaxis in Patients with Haematological Disease. Liver Int. 2013, 33, 1203-1210. [CrossRef] [PubMed]

35. Koskinas, J.; Deutsch, M.; Adamidi, S.; Skondra, M.; Tampaki, M.; Alexopoulou, A.; Manolakopoulos, S.; Pectasides, D. The Role of Tenofovir in Preventing and Treating Hepatitis B Virus (HBV) Reactivation in Immunosuppressed Patients. A Real Life Experience from a Tertiary Center. Eur. J. Intern. Med. 2014, 25, 768-771. [CrossRef] [PubMed]

36. Tseng, C.; Chen, T.; Hsu, Y.; Chang, C.; Lin, J.; Mo, L. Comparative Effectiveness of Nucleos(t)ide Analogues in Chronic Hepatitis B Patients Undergoing Cytotoxic Chemotherapy. Asia-Pac. J. Clin. Oncol. 2016, 12, 421-429. [CrossRef] [PubMed]

37. Marrone, A.; Capoluongo, N.; D'Amore, C.; Pisaturo, M.; Esposito, M.; Guastafierro, S.; Siniscalchi, I.; Macera, M.; Boemio, A.; Onorato, L.; et al. Eighteen-Month Lamivudine Prophylaxis on Preventing Occult Hepatitis B Virus Infection Reactivation in Patients with Haematological Malignancies Receiving Immunosuppression Therapy. J. Viral Hepat. 2018, 25, 198-204. [CrossRef]

38. Chew, E.; Thursky, K.; Seymour, J.F. Very Late Onset Hepatitis-B Virus Reactivation Following Rituximab despite Lamivudine Prophylaxis: The Need for Continued Vigilance. Leuk. Lymphoma 2014, 55, 938-939. [CrossRef] [PubMed]

39. Dai, M.-S.; Chao, T.-Y.; Kao, W.-Y.; Shyu, R.-Y.; Liu, T.-M. Delayed Hepatitis B Virus Reactivation after Cessation of Preemptive Lamivudine in Lymphoma Patients Treated with Rituximab Plus CHOP. Ann. Hematol. 2004, 83, 769-774. [CrossRef]

40. Sarmati, L.; Andreoni, M.; Antonelli, G.; Arcese, W.; Bruno, R.; Coppola, N.; Gaeta, G.; Galli, M.; Girmenia, C.; Mikulska, M.; et al. Recommendations for Screening, Monitoring, Prevention, Prophylaxis and Therapy of Hepatitis B Virus Reactivation in Patients with Haematologic Malignancies and Patients who Underwent Haematologic Stem Cell Transplantation-A Position Paper. Clin. Microbiol. Infect. 2017, 23, 935-940. [CrossRef]

41. Pawłowska, M.; Flisiak, R.; Gil, L.; Horban, A.; Hus, I.; Jaroszewicz, J.; Lech-Maranda, E.; Styczyński, J. Prophylaxis of Hepatitis B Virus (HBV) Infection Reactivation-Recommendations of the Working Group for Prevention of HBV Reactivation. Clin. Exp. Hepatol. 2019, 5, 195-202. [CrossRef] [PubMed]

42. Loras, C.; Gisbert, J.P.; Minguez, M.; Merino, O.; Bujanda, L.; Saro, C.; Domenech, E.; Barrio, J.; Andreu, M.; Ordas, I.; et al. Liver Dysfunction Related to Hepatitis B and C in Patients with Inflammatory Bowel Disease Treated with Immunosuppressive Therapy. Gut 2010, 59, 1340-1346. [CrossRef]

43. Morisco, F.; Castiglione, F.; Rispo, A.; Stroffolini, T.; Sansone, S.; Vitale, R.; Guarino, M.; Biancone, L.; Caruso, A.; D’Inca, R.; et al. Effect of Immunosuppressive Therapy on Patients with Inflammatory Bowel Diseases and Hepatitis B or C Virus Infection. J. Viral Hepat. 2013, 20, 200-208. [CrossRef] [PubMed]

44. Pérez-Alvarez, R.; Díaz-Lagares, C.; Garcia-Hernandez, F.J.; Lopez-Roses, L.; Zeron, P.B.; Pérez-De-Lis, M.; Retamozo, S.; Bové, A.; Bosch, X.; Sanchez-Tapias, J.-M.; et al. Hepatitis B Virus (HBV) Reactivation in Patients Receiving Tumor Necrosis Factor (TNF)-Targeted Therapy. Medicine 2011, 90, 359-371. [CrossRef] [PubMed]

45. Shah, R.; Ho, E.Y.; Kramer, J.R.; Richardson, P.; Sansgiry, S.; El-Serag, H.B.; Hou, J.K. Hepatitis B Virus Screening and Reactivation in a National VA Cohort of Patients with Inflammatory Bowel Disease Treated with Tumor Necrosis Factor Antagonists. Dig. Dis. Sci. 2018, 63, 1551-1557. [CrossRef] [PubMed]

46. Clarke, W.T.; Amin, S.S.; Papamichael, K.; Feuerstein, J.D.; Cheifetz, A.S. Patients with Core Antibody Positive and Surface Antigen Negative Hepatitis B (anti-HBc+, HBsAg-) on Anti-TNF Therapy have a Low Rate of Reactivation. Clin. Immunol. 2018, 191, 59-62. [CrossRef] [PubMed] 
47. Solay, A.H.; Acar, A.; Eser, F.; Kuscu, F.; Tutuncu, E.E.; Kul, G.; Senturk, G.C.; Gurbuz, Y.; Solay, A.H. Reactivation Rates in Patients Using Biological Agents, with Resolved HBV Infection or Isolated Anti-HBc IgG Positivity. Turk. J. Gastroenterol. 2018, 29, 561-565. [CrossRef]

48. Papa, A.; Felice, C.; Marzo, M.; Andrisani, G.; Armuzzi, A.; Covino, M.; Mocci, G.; Pugliese, D.; De Vitis, I.; Gasbarrini, A.; et al. Prevalence and Natural History of Hepatitis B and C Infections in a Large Population of IBD Patients Treated with Anti-Tumor Necrosis Factor- $\alpha$ Agents. J. Crohns Coliti 2013, 7, 113-119. [CrossRef] [PubMed]

49. Sayar, S.; Kurbuz, K.; Kahraman, R.; Ozturk, O.; Caliskan, Z.; Doganay, H.L.; Ozdil, K. Risk of Hepatitis B Reactivation during Anti-TNF Therapy; Evaluation of Patients with Past Hepatitis B Infection. Turk. J. Gastroenterol. 2020, 31, 522-528. [CrossRef] [PubMed]

50. Rahier, J.; Magro, F.; Abreu, C.; Armuzzi, A.; Ben-Horin, S.; Chowers, Y.; Cottone, M.; De Ridder, L.G.D.; De Ehehalt, R. Second European Evidence-Based Consensus on the Prevention, Diagnosis and Management of Opportunistic Infections in Inflammatory Bowel Disease. J. Crohns Coliti 2014, 8, 443-468. [CrossRef] [PubMed]

51. Armstrong, A.W.; Read, C. Pathophysiology, Clinical Presentation, and Treatment of Psoriasis. JAMA 2020, 323, 1945-1960. [CrossRef] [PubMed]

52. Chiu, H.-Y.; Chen, C.-H.; Wu, M.-S.; Cheng, Y.-P.; Tsai, T.-F. The Safety Profile of Ustekinumab in the Treatment of Patients with Psoriasis and Concurrent Hepatitis B or C. Br. J. Dermatol. 2013, 169, 1295-1303. [CrossRef] [PubMed]

53. Ting, S.-W.; Chen, Y.-C.; Huang, Y.-H. Risk of Hepatitis B Reactivation in Patients with Psoriasis on Ustekinumab. Clin. Drug Investig. 2018, 38, 873-880. [CrossRef] [PubMed]

54. Snast, I.; Atzmony, L.; Braun, M.; Hodak, E.; Pavlovsky, L. Risk for Hepatitis B and C Virus Reactivation in Patients with Psoriasis on Biologic Therapies: A Retrospective Cohort Study and Systematic Review of the Literature. J. Am. Acad. Dermatol. 2017, 77, 88-97.e5. [CrossRef] [PubMed]

55. Piaserico, S.; Dapavo, P.; Conti, A.; Gisondi, P.; Russo, F.P. Adalimumab is a Safe Option for Psoriasis Patients with Concomitant Hepatitis B or C Infection: A Multicentre Cohort Study of 37 Patients and Review of the Literature. J. Eur. Acad. Dermatol. Venereol. 2017, 31, 1853-1859. [CrossRef] [PubMed]

56. Almutairi, N.; Abouzaid, H.A. Safety of Biologic Agents for Psoriasis in Patients with Viral Hepatitis. J. Dermatol. Treat. 2018, 29, 553-556. [CrossRef]

57. Cantini, F.; Boccia, S.; Goletti, D.; Iannone, F.; Leoncini, E.; Panic, N.; Prignano, F.; Gaeta, G.B. HBV Reactivation in Patients Treated with Antitumor Necrosis Factor-Alpha (TNF- $\alpha$ ) Agents for Rheumatic and Dermatologic Conditions: A Systematic Review and Meta-Analysis. Int. J. Rheumatol. 2014, 2014, 926836. [CrossRef] [PubMed]

58. Singh, J.A.; Saag, K.G.S.L.B., Jr.; Akl, E.A.; Bannuru, R.; Sullivan, M.; Vaysbrot, E.; McNaughton, C.; Osani, M.; Shmerling, R.H. 2015 American College of Rheumatology Guideline for the Treatment of Rheumatoid Arthritis. Arthritis Rheum. 2016, 68, 1-25. [CrossRef]

59. Ramiro, S.; Smolen, J.S.; Landewé, R.; Van Der Heijde, D.; Dougados, M.; Emery, P.; De Wit, M.; Cutolo, M.; Oliver, S.; Gossec, L. Pharmacological Treatment of Psoriatic Arthritis: A Systematic Literature Review for the 2015 Update of the EULAR Recommendations for the Management of Psoriatic Arthritis. Ann. Rheum. Dis. 2016, 75, 490-498. [CrossRef] [PubMed]

60. Lee, Y.H.; Song, G.G. Comparative Efficacy and Safety of Tofacitinib, Baricitinib, Upadacitinib, Filgotinib and Peficitinib as Monotherapy for Active Rheumatoid Arthritis. J. Clin. Pharm. Ther. 2020, 45, 674-681. [CrossRef] [PubMed]

61. Laohapand, C.; Arromdee, E.; Tanwandee, T. Long-Term Use of Methotrexate does not Result in Hepatitis B Reactivation in Rheumatologic Patients. Hepatol. Int. 2015, 9, 202-208. [CrossRef] [PubMed]

62. Flowers, M.A.; Heathcote, J.; Wanless, I.R.; Sherman, M.; Reynolds, W.J.; Cameron, R.G.; Levy, G.A.; Inman, R.D. Fulminant Hepatitis as a Consequence of Reactivation of Hepatitis B Virus Infection after Discontinuation of Low-Dose Methotrexate Therapy. Ann. Intern. Med. 1990, 112, 381. [CrossRef] [PubMed]

63. Hagiyama, H.; Kubota, T.; Komano, Y.; Kurosaki, M.; Watanabe, M.; Miyasaka, N. Fulminant Hepatitis in an Asymptomatic Chronic Carrier of Hepatitis B Virus Mutant after Withdrawal of Low-Dose Methotrexate Therapy for Rheumatoid Arthritis. Clin. Exp. Rheumatol. 2004, 22, 375-376.

64. Ito, S.; Nakazono, K.; Murasawa, A.; Mita, Y.; Hata, K.; Saito, N.; Kikuchi, M.; Yoshida, K.; Nakano, M.; Gejyo, F. Development of Fulminant Hepatitis B (Precore Variant Mutant Type) after the Discontinuation of Low-Dose Methotrexate Therapy in a Rheumatoid Arthritis Patient. Arthritis Rheum. 2001, 44, 339-342. [CrossRef]

65. Narvaez, J.; Rodriguez-Moreno, J.; Martinez-Aguilá, M.D.; Clavaguera, M.T. Severe Hepatitis Linked to B Virus Infection after Withdrawal of Low Dose Methotrexate Therapy. J. Rheumatol. 1998, 25, 2037-2038. [PubMed]

66. Gwak, G.-Y.; Koh, K.C.; Kim, H.-Y. Fatal Hepatic Failure Associated with Hepatitis B Virus Reactivation in a Hepatitis B Surface Antigen-Negative Patient with Rheumatoid Arthritis receiving Low Dose Methotrexate. Clin. Exp. Rheumatol. 2007, 25, 888-889. [PubMed]

67. Chen, M.-H.; Chen, M.-H.; Liu, C.-Y.; Tsai, C.-Y.; Huang, D.-F.; Lin, H.-Y.; Lee, M.-H.; Huang, Y.-H. Hepatitis B Virus Reactivation in Rheumatoid Arthritis Patients undergoing Biologics Treatment. J. Infect. Dis. 2017, 215, 566-573. [CrossRef] [PubMed]

68. Ryu, H.H.; Lee, E.Y.; Shin, K.; Choi, I.A.; Lee, Y.J.; Yoo, B.; Park, M.-C.; Park, Y.-B.; Bae, S.-C.; Yoo, W.H.; et al. Hepatitis B Virus Reactivation in Rheumatoid Arthritis and Ankylosing Spondylitis Patients treated with Anti-TNF $\alpha$ Agents: A Retrospective Analysis of 49 Cases. Clin. Rheumatol. 2012, 31, 931-936. [CrossRef] [PubMed] 
69. Fukuda, W.; Hanyu, T.; Katayama, M.; Mizuki, S.; Okada, A.; Miyata, M.; Handa, Y.; Hayashi, M.; Koyama, Y.; Arii, K.; et al. Incidence of Hepatitis B Virus Reactivation in Patients with Resolved Infection on Immunosuppressive Therapy for Rheumatic Disease: A Multicentre, Prospective, Observational Study in Japan. Ann. Rheum. Dis. 2017, 76, 1051-1056. [CrossRef] [PubMed]

70. Fukuda, W.; Hanyu, T.; Katayama, M.; Mizuki, S.; Okada, A.; Miyata, M.; Handa, Y.; Hayashi, M.; Koyama, Y.; Arii, K.; et al. Risk Stratification and Clinical Course of Hepatitis B Virus Reactivation in Rheumatoid Arthritis Patients with Resolved Infection: Final Report of a Multicenter Prospective Observational Study at Japanese Red Cross Hospital. Arthritis Res. 2019, $21,255$. [CrossRef] [PubMed]

71. Lee, Y.H.; Bae, S.-C.; Song, G.G. Hepatitis B Virus Reactivation in HBsAg-Positive Patients with Rheumatic Diseases Undergoing Anti-Tumor Necrosis Factor Therapy or DMARDs. Int. J. Rheum. Dis. 2013, 16, 527-531. [CrossRef]

72. Varisco, V.; Viganò, M.; Batticciotto, A.; Lampertico, P.; Marchesoni, A.; Gibertini, P.; Pellerito, R.; Rovera, G.; Caporali, R.; Todoerti, M.; et al. Low Risk of Hepatitis B Virus Reactivation in HBsAg-negative/Anti-HBc-Positive Carriers Receiving Rituximab for Rheumatoid Arthritis: A Retrospective Multicenter Italian Study. J. Rheumatol. 2016, 43, 869-874. [CrossRef] [PubMed]

73. Urata, Y.; Uesato, R.; Tanaka, D.; Kowatari, K.; Nitobe, T.; Nakamura, Y.; Motomura, S. Prevalence of Reactivation of Hepatitis B Virus Replication in Rheumatoid Arthritis Patients. Mod. Rheumatol. 2011, 21, 16-23. [CrossRef] [PubMed]

74. Nakamura, J.; Nagashima, T.; Nagatani, K.; Yoshio, T.; Iwamoto, M.; Minota, S. Reactivation of Hepatitis B Virus in Rheumatoid Arthritis Patients Treated with Biological Disease-Modifying Antirheumatic Drugs. Int. J. Rheum. Dis. 2016, 19, 470-475. [CrossRef] [PubMed]

75. Harigai, M.; Winthrop, K.; Takeuchi, T.; Hsieh, T.-Y.; Chen, Y.-M.; Smolen, J.S.; Burmester, G.; Walls, C.; Wu, W.-S.; Dickson, C.; et al. Evaluation of Hepatitis B Virus in Clinical Trials of Baricitinib in Rheumatoid Arthritis. RMD Open 2020, 6, e001095. [CrossRef]

76. Chen, Y.-M.; Yang, S.-S.; Chen, D.-Y. Risk-Stratified Management Strategies for HBV Reactivation in RA Patients receiving Biological and Targeted Therapy: A Narrative Review. J. Microbiol. Immunol. Infect. 2019, 52, 1-8. [CrossRef] [PubMed]

77. McGinley, M.P.; Goldschmidt, C.H.; Rae-Grant, A.D. Diagnosis and Treatment of Multiple Sclerosis: A Review. JAMA 2021, 325, 765-779. [CrossRef]

78. Ciardi, M.R.; Iannetta, M.; Zingaropoli, M.A.; Salpini, R.; Aragri, M.; Annecca, R.; Pontecorvo, S.; Altieri, M.; Russo, G.; Svicher, V.; et al. Reactivation of Hepatitis B Virus with Immune-Escape Mutations After Ocrelizumab Treatment for Multiple Sclerosis. Open Forum Infect Dis. 2018, 6, 365. [CrossRef] [PubMed]

79. Epstein, D.J.; Dunn, J.; Deresinski, S. Infectious Complications of Multiple Sclerosis Therapies: Implications for Screening, Prophylaxis, and Management. Open Forum Infect. Dis. 2018, 5, ofy174. [CrossRef]

80. Dong, E.; Du, H.; Gardner, L. An Interactive Web-Based Dashboard to Track COVID-19 in Real Time. Lancet Infect. Dis. 2020, 20, 533-534. [CrossRef]

81. World Health Organization. COVID-19 Clinical Management: Living Guidance; WHO: Geneve, Switzerland, 2021.

82. Ghosn, L.; Chaimani, A.; Evrenoglou, T.; Davidson, M.; Graña, C.; Schmucker, C.; Bollig, C.; Henschke, N.; Sguassero, Y.; Nejstgaard, C.H.; et al. Interleukin-6 Blocking Agents for Treating COVID-19: A Living Systematic Review. Cochrane Database Syst. Rev. 2021, 2021, CD013881. [CrossRef]

83. Liu, J.; Wang, T.; Cai, Q.; Sun, L.; Huang, D.; Zhou, G.; He, Q.; Wang, F.; Liu, L.; Chen, J. Longitudinal Changes of Liver Function and Hepatitis B Reactivation in COVID-19 Patients with Pre-Existing Chronic Hepatitis B Virus Infection. Hepatol. Res. 2020, 50, 1211-1221. [CrossRef] [PubMed]

84. Mori, S. Hepatitis B Virus Reactivation Associated with Antirheumatic Therapy: Risk and Prophylaxis Recommendations. World J. Gastroenterol. 2015, 21, 10274-10289. [CrossRef] [PubMed]

85. Rodríguez-Tajes, S.; Miralpeix, A.; Costa, J.; López-Suñé, E.; Laguno, M.; Pocurull, A.; Lens, S.; Mariño, Z.; Forns, X. Low Risk of Hepatitis B Reactivation in Patients with Severe COVID-19 who Receive Immunosuppressive Therapy. J. Viral Hepat. 2021, 28, 89-94. [CrossRef] [PubMed] 